\title{
The Importance of Academic Writing Knowledge To Second- Year Students to Foster Them Achieve University Success
}

\begin{abstract}
:
Writing the different academic papers such as essays and articles at the university requires from students to follow certain conventions proper to formal and cautious academic writing. This paper aims to explore second-year students' perceptions and attitudes of academic writing and its prominent features at the Department of Letters and English Language at the University of Constantine1. The choice of second year students is because they have been exposed to certain skills of writing in their first year, as how to write the different types of sentences and short paragraphs. For gathering data, two questionnaires were administered to eight teachers of writing, and to a population of sixty second-year students. The analysis of the data confirmed that students lack knowledge of the features of academic writing.
\end{abstract}

Key words: academic writing, academic features; academic writing knowledge.

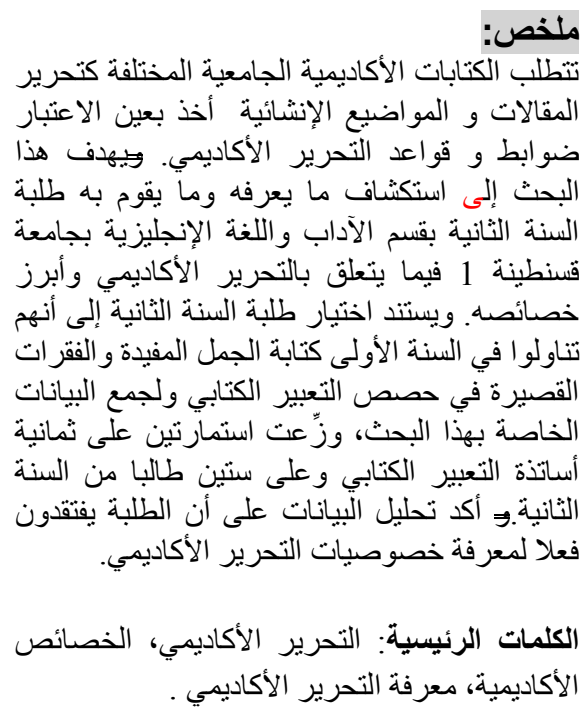

\section{Mechitoua Nassima}

Faculty of Letters and Languages

Department of Foreign Languages

University of Mentouri

Constantine

\section{Introduction :}

The mastery of writing academic papers such as essays and research papers, as well as being aware of the importance of academic writing knowledge at the university level is highly required. The university is always described as a discourse community which agrees on different conventions and rules. This means that writing in academic contexts involves following certain conventions 
which have been noticed absent in students' writings. This paper discusses academic writing; its aspects and conventions. Based on the analysis of teachers' and students' questionnaires, a clear picture will be given on whether second-year students at the University of Constantine 1 have knowledge of academic writing. The paper ends with suggestions that could help students write academic English at the University.

\section{Academic Writing: An Overview}

Writing has different forms and aspects as writing for personal purposes or letters, writing research articles, books, essays, and dissertations. The latter, as a matter of fact, require academic writing, a type of writing that students are expected to produce while at the university. Clark (2003) sees that academic writing is "at an even higher level of formality and is governed by even stricter conventions; thus, academic writing represents what we call formal Standard English" (p. 320). To Thaiss and Zawaki (2006), academic writing is any writing that fulfills the purpose of education in a college or university in response to an academic assignment, or professional writing. It is what both teachers and researchers do for publications and conferences attended by other field specialists. In the same vein, Greene (2012) considers that academic writing is a formal language which is written by scholars to present their ideas and concepts objectively to their peers to an academic community.

Academic writing is a special genre of writing because it is governed by specific and prominent conventions and rules, and it becomes paramount that students have to be aware of such features that govern academic writing. The basic feature is that in academic writing, the use of an objective style rather than a personal one is more recommended. This appears in avoiding the use of personal pronouns as 'I', 'my', 'we', and expressions such as, in my opinion', 'I think'. The other prominent feature is that academic writing always employs a formal style. In effect, the level of formality is one of the qualities that distinguish academic writing from other kinds of writing (Murray \& Hughes, 2008 ) and thus idiomatic and colloquial vocabulary such as 'kids, boss' are not accepted. In the same vein, contracted forms as "don't, can't, shouldn't" and others are not appropriate in academic writing. Another crucial feature of academic writing is cautious writing. Cautious writing or 'hedging' is a "strategy when a speaker or writer wishes to avoid coming straight to the point or to avoid speaking directly" (Nurmukanedov \& Kim, 2009, p. 274). Different types of hedges can be adverbs of frequency 'frequently, almost, and probably'. They aim to avoid writers' definite claims. Using citations 'quoting, paraphrasing, summarizing' is another convention of academic writing. A well written academic text is based on the sources that are used to support a claim or a position. As Bowker (2007) claims, "citing the work of other authors is 
central to academic writing because it shows you have read the literature" (p. 2).

\section{Raising Students Awareness of the Importance of Academic Writing}

Students, especially second-year students (of our interest) should be aware of the importance of academic writing knowledge. Generally, there are some attitudes or procedures that may help students obtain knowledge of and about academic writing. Firstly, students should receive explicit teaching of all what is related to academic writing knowledge, as to present to them the main conventions of academic writing, as well as the differences that exist between academic and non-academic writing. In this respect, introducing second-year composition students to the conventions of academic discourse provides them with the required knowledge that they can use in their formal writings (Thonney, 2011).These students could be, for example, exposed to texts that illustrate the conventions of academic writing, since these models are expected to provide them with particular information about the forms of lexical and syntactical features required by this genre. Thirdly, extensive practice in writing the different formats of texts such as essays and research papers is a crucial step to make students aware of academic writing knowledge.

\section{Research Method}

\subsection{Participants}

The research population is composed of eight teachers of Written Expression, and sixty second-year students from the Department of Letters and English Language University of Constantine1. The reason behind choosing second-year students is that they have [already] been introduced to certain grammatical rules which are related to academic writing such as the present simple and conjunctions. The other reason is that second-years start to deal with academic texts such as essays and research papers. This allows us to check their potential of academic English.

\subsection{Materials, Procedure and Data Collection}

Data are gathered through techniques such as interviews, observation, and questionnaires (Biggam, 2008).The data of the present research are gathered from teachers and students' questionnaires, and from classroom observation. The teachers' questionnaire consists of eighteen close-ended and multiple choice questions, and the students' questionnaire consists of sixteen open-ended and multiple choice questions. The data gathered from these questionnaires are analyzed to check the hypothesis. It is worth mentioning that I take into consideration while analysing the results only the questions which are related to academic writing knowledge in both teachers' and students' questionnaires. 
4.3. Results

\subsubsection{Teachers' Questionnaire}

The analysis of the teachers' questionnaire is as set forth in Table 1, and it reveals that of the total respondents $(\mathrm{N}=8), 75 \%$ saidthat second-year students have a limited knowledge about academic writing; while $25 \%$ said that they have no knowledge of such features. On a question whether their students write academically, $75 \%$ of the respondents pointed out that their students do not write academically; against $25 \%$ who said they do. On a third question about the supposed reasons that make students not write academically, $50 \%$ of the respondents agreed that the lack of explicit instructions and exposure to academic texts are the main reasons. Accordingly, they suggested that students need to have explicit instructions about the nature of academic writing.

\begin{tabular}{|c|c|c|}
\hline $\begin{array}{l}\text { 1. What is your opinion of second year academic writing } \\
\text { knowledge? }\end{array}$ & & \\
\hline a. have knowledge & 00 & $0 \%$ \\
\hline b. limited knowledge & 06 & $75 \%$ \\
\hline c. do not have knowledge & 02 & $25 \%$ \\
\hline Total & 08 & $100 \%$ \\
\hline \multicolumn{3}{|l|}{ 2. Do students write academically in their assignments? } \\
\hline a. Yes & 02 & $25 \%$ \\
\hline b. No & 06 & $75 \%$ \\
\hline Total & 08 & $100 \%$ \\
\hline \multicolumn{3}{|l|}{$\begin{array}{l}\text { 3. In your opinion, what makes students not to write } \\
\text { academically? }\end{array}$} \\
\hline a. lack of explicit instructions & 01 & $12,50 \%$ \\
\hline b. lack of practice & 02 & $25 \%$ \\
\hline c. no exposure to academic texts & 01 & $12,50 \%$ \\
\hline d. $a+b$ & 04 & $50 \%$ \\
\hline Total & 08 & $100 \%$ \\
\hline
\end{tabular}

Table 1.Teachers' Perceptions towards Second Year Students' Academic Writing Knowledge

\subsubsection{Students' Questionnaire}

The results in Table 2 show that $41,66 \%$ say they write academically their writing production; against $11,66 \%$ who said that they do not write academically. At the same time, $63,33 \%$ do not know that academic writing has certain conventions; against $36,66 \%$ say that they know that academic writing is characterized by different features. In addition, $95 \%$ of respondents do not know what the main features of academic writing are; against $5 \%$ who said they know them. 
The Importance of Academic Writing Knowledge

To Second- Year Students to Foster Them Achieve University Success

\begin{tabular}{|c|c|c|}
\hline $\begin{array}{l}\text { 1. Do you write the different kinds of writing such as essays } \\
\text { research papers academically? }\end{array}$ & & \\
\hline a. Yes & 25 & $41,66 \%$ \\
\hline b. No & 07 & $11,66 \%$ \\
\hline c. Don't know & 28 & $46,66 \%$ \\
\hline Total & 60 & $100 \%$ \\
\hline $\begin{array}{l}\text { 2. Do you know that academic writing is characterized by } \\
\text { different features? }\end{array}$ & & \\
\hline a. yes & 22 & $36,66 \%$ \\
\hline b. no & 38 & $63,33 \%$ \\
\hline Total & 60 & $100 \%$ \\
\hline $\begin{array}{l}\text { 3. Do you know what are the main features of academic writing? If } \\
\text { yes, name them. }\end{array}$ & & \\
\hline a. yes & 03 & $05 \%$ \\
\hline b. no & 57 & $95 \%$ \\
\hline $\begin{array}{l}\text { Total } \\
\end{array}$ & 60 & $100 \%$ \\
\hline $\begin{array}{l}\text { 4. Do you receive explicit instructions and sample texts about how } \\
\text { academic writing should be? }\end{array}$ & & \\
\hline a. yes & 19 & $31,66 \%$ \\
\hline b. no & 41 & $68,33 \%$ \\
\hline Total & 60 & $100 \%$ \\
\hline
\end{tabular}

Table 2.Students' Attitudes to Academic Writing Knowledge

\subsection{Discussion of Results}

The analysis of students' questionnaire and classroom observation revealed that second-year students have a limited knowledge about academic writing. This appeared from their answers on the nature of academic writing, i.e., the definition of academic writing, the salient features of academic writing where $(95 \%)$ of the total respondents $(\mathrm{N}=60)$ said that they do not know the conventions of academic writing. Yet, there was only one student who answered that citations and form are important rules of academic writing. At the same time, students think that writing is caring just about grammar, the different paragraphs in a composition, and the amount of information about a particular topic. These results might be an outcome of the lack of explicit instructions about academic writing knowledge in Written Expression courses. Moreover, the lack of extensive practice and exposure to authentic academic texts that are considered essential to help students write academically. One possible interpretation to this could be the insufficient time devoted to teach writing. This means that because second-years have only two sessions (three hours) per week of Written Expression, thus teachers could not provide them 
with all the necessary aspects and details about academic writing. To explain more, if we take the two sessions of Written Expression: one for giving background knowledge and the other for practice, of course, one session will not be enough to cover all sides of writing, and without forgetting that writing is a process where students start from gathering ideas until to arrive to the final product.

The second finding is related to teachers' attitudes of their students' academic writing knowledge (Table 1), where $75 \%$ say that their students' writings are not written according to academic standards. Moreover, $50 \%$ of the total respondents $(\mathrm{N}=08)$ stated that providing students with appropriate guidance and explicit instructions about the nature of academic writing during Written Expression courses with adequate and intensive practice is expected to help them acquire the necessary and efficient knowledge regarding academic writing discipline. These obtained results are explained by the fact that the emphasis should be on academic writing knowledge which might be brought by the writing demands of the academic contexts. In other words, academic writing knowledge might be a matter of selected writing curriculum, i.e., teachers decide together on a multidimensional writing program including detailed academic writing courses that would be the main objective of teaching writing at the university.

\section{Conclusion}

This paper is about the analysis of two questionnaires, one administrated to eight Written Expression teachers and the other to sixty second-year students on the issue of the inability of second-year students to write according to academic writing. The results of the analysis of the questionnaires has showed that first, teachers agree that second-year students at the Department of Letters and English Language at the University of Constantine 1 are not aware of the nature of academic writing and its prominent features, and that consequently students' written productions are not written according to academic standards. Second and on the same keel, the analysis of the students' questionnaire revealed that they do not receive explicit instructions and guiding about the nature of academic writing, either.

In the light of this, it appears very clear that it grows urgent that teachers should provide explicit instructions concerning academic writing features and give intensive practice to their students so that they internalize such features. Likewise, it is hoped that -in concert-an awareness and a robust implementation of the aspects and features of academic writing would in the short run have a positive impact on second-year students' written -thus academic-production; and in the long run their future academic career.

\section{Works cited}


Biggam, J. (2008). Succeeding with Your Master's Dissertation: a Step-by-step Handbook. New York: Open University Press.

Bowker, N. (Ed.). (2007). Academic Writing: a Guide to Tertiary Level Writing. Massey University.

Clark, I. L. (2003).Concepts in Composition: Theory and Practice in the Teaching of Writing. London: Lawrence Erlbaum Associates.

Greene, S. (2012). Inquiry to Academic Writing: A Text and Reader. $\left(2^{\text {nd }} \mathrm{ed}\right)$. Dedford St. Martins.

Murray, N. \& Hughes, G. (2008).Writing up Your University Assignments and Research Projects: A Practical Handbook. New York: Open University Press.

Nurmukhamedov, U. \& Kim, S.H. (2009). 'Would you perhaps consider': Hedged Comments in ESL Writing ELT Journal, 64 (3), 272-282.

Thaiss, CH. \&Zawacki, T.M. (2006).Engaged Writers, Dynamic Disciplines: Research on the Academic Writing Life. Portsmouth: Boynton cook pub Heinnemunn.

Thonney, T (2011). Teaching the Conventions of Academic Discourse. TETYC, 347-362. 